\title{
TRICHODERMA SPP ANTAGONISM TO PHYTOPATHOGENS CAUSING CASSAVA ROOT ROT IN ALAGOAS
}

\section{REVIEW ARTICLE}

SILVA, Izael Oliveira ${ }^{1}$

AMORIM, Edna Peixoto da Rocha ${ }^{2}$

JUNIOR, Nelson Augusto Nascimento ${ }^{3}$

PEIXINHO, Georgia Souza ${ }^{4}$

CARNAÚBA, Juliana Paiva ${ }^{5}$

NETO, Vicente Ferreira de Araujo ${ }^{6}$

SILVA, Izael Oliveira. Et al. Trichoderma spp antagonism to phytopathogens causing cassava root rot in alagoas. Revista Científica Multidisciplinar Núcleo do Conhecimento. Year 05, Ed. 06, Vol. 12, pp. 149-177. June 2020. ISSN: 2448-0959,

${ }^{1} \mathrm{PhD}$ in Plant Protection, Master in Plant Production Master's degree, Bachelor's degree and Bachelor's degree in Biological Sciences.

${ }^{2} \mathrm{PhD}$ in Agronomy (Agriculture). Master's degree in Phytopathology. Specialization in Didactics for Higher Education. Graduation in Agronomy.

${ }^{3} \mathrm{PhD}$ in Plant Protection. Master's degree in Agronomy (Irrigation and Drainage). Graduation in Agronomy.

${ }^{4}$ Master's degree in Irrigated Horticulture. Graduation in Agronomy.

${ }^{5} \mathrm{PhD}$ in Phytopathology. Master's degree in Agronomy (Plant Production and Plant Protection). Improvement in Improvement in Biological Sciences. Graduation in Agronomy.

${ }^{6}$ Graduating in Agronomy. 
Access link: https://www.nucleodoconhecimento.com.br/agronomy-en/trichodermaantagonism

\section{SUMMARY}

Several are phytopathogens that limit the production of cassava (Manihot esculata Crants) being rot of the roots to which they marry the greatest loss in the crop reaching $70 \%$. This culture is of high interest to the Northeast region of Brazil, providing great losses. The difficulties in management have directed the search for alternatives, among which, biocontrollers have shown significant results. This literature review aimed to gather information related to the rot of cassava root cv Rosinha, the main phytopathogens and antagonistic activities of Trichoderma in the control of diseases in the state of Alagoas. A bibliographic survey was carried out in the databases Scielo, Google Acadêmico, Capes portal (theses and dissertations), journals and books. To obtain information on: root rot of table cassava, Trichoderma spp., as a biocontrol agent of phytopathogens.

Keywords: Tuberous root, biological control, phytopathology.

\section{INTRODUCTION}

Due to its nutritional value, Manihot esculenta Crantz stands out in Brazil and in the world with significant economic and social contribution due to its versatility, as it is used in both animal and human food and widely used in industry. The crop exerts a significant support to the population with low purchasing power, because besides being a nutritious source it is also a generator of income in family agriculture (NOTARO et al. 2013).

In the world, the consumption of cassava and its derivatives are in the sixth position in the ranking being soybeans, wheat, rice, corn and potatoes the crops that occupy the first positions according to fao data (2012). Brazil is the fourth largest producer in the world, with an estimated harvest for 2016 of 25 million tons (IBGE, 2015). 
Of great versatility, the crop is fully used, not only the aerial part (leaves and stems) but also the root. The leaves have their use in human (supplement) and animal (crushed) food. The stems, in animal feed, in the form of silages and hays and still in natura. The root, in human food, animal and also by industries, mainly flour, starches, biodegradable plastics, textile products and biofuel (CONAB, 2013).

Cassava culture faces many challenges, including phytosanitary problems (NASCIMENTO JÚNIOR, 2015). Several diseases have already been reported in the culture, among them, root rot, whose agents may be Lasiodiplodia sp., Pythium sp., Rosellinia sp., Fusarium sp., Neoscytalidium lignicola, Phytophthora drechsleri Tucker however, the last three phytopathogens are the most frequently involved in root rot in the state of Alagoas (Figure 1) and in most producing regions. Information on the rot of cassava roots is still incipient and is of paramount importance to serve as a tool in decision making on the best strategy to use (MASSOLA JR; BEDENDO, 2005; MUNIZ et al., 2006; NOTARO et al., 2013; SILVA, 2013; FUKUDA, I'M NOT GOING TO BE OTSUBO, 2015).

Among the microorganisms causing cassava root rot P. drechsleri and F. solani, they are the most important due to the scope and severity causing significant losses in production. In dense and acidified soils the occurrence of Fusarium sp., is more frequent, and one of the characteristics of this pathogens is to cause damage to the stem near the soil by infection of the xylemic vessels and consequently interfere in the circulation of the sap, thus causing indirect rot of the root in any cause of plant development. Unlike Phytophthora, whose symptoms provoked in the roots are brown in color and soft-consistency rot that exude a liquid with bad smell, already the rots of Fusarium sp., without apparent disturbances in the tissues with signs of dehydration and mummified appearance of a dry rot (MOURA; SILVA, 1997; POLTRONIERI et al., 2001; SILVA, I'M not going to TEIXEIRAS, 2012).

As protective and root rot control measures, physical and chemical soil management is used, but the use of tolerant varieties associated with cultural practices such as crop rotation and cultivation system has been positively supported. Nascimento Júnior (2015), highlights that it is of fundamental importance to know the edapho-climatic 
conditions of the cultivation region and the use of appropriate techniques that can be adopted by the farmer, to have an economic return within a sustainable agricultural system. The alternative control of phytopathogens with antagonists, especially trichoderma species, has already been studied, due to the worldwide interest of using products that are less aggressive to the environment (SOUSA et al., 2012; SILVA et al., 2014). For Robbs (1992) and Barbosa; Meza (2009) the competition for food and antibiosis, are the mechanisms most frequently used by some species of Trichoderma, being therefore considered an excellent biocontrol agent.

In view of the above, the objective of the present work was to perform a bibliographic review about the main phytopathogens and the potential of Trichoderma antagonism involved with cassava root rot in the state of Alagoas.

\section{METHODOLOGY}

The present study consists of a literature review, conducted between December 2014 and March 2016, in which a consultation was made to scientific articles, selected through the search in the database of google academic, LILACS, MEDLINE, SciELO, portal of Capes (theses and dissertations), journals and books. Of the numerous related articles, 84 of them were used. As descriptors we used: root rot, biological control of phytopathogens, phytosanity.

\section{LITERATURE REVIEW}

\subsection{CASSAVA CULTIVATION}

Cassava, a crop of great interest for the Brazilian Northeast, notably for the State of Alagoas, is a perennial, shrubby plant, belonging to the Euphorbiaceous family, rich in starch, used in human and animal food or as a raw material for various industries (FRAIRE FILHO; BAHIA, 2015).

Nascimento Júnior (2015), emphasizes the advantages of this crop, due to its rusticity, low cost, adaptation in relation to the climate, soil and its nutritional characteristics that 
are related to the large accumulation of starch in its roots, as well as proteins and amino acids in the leaves. It is a plant originating in the tropical regions of South America, but which had as places of its domestication Southeast Asia, Africa and Tropical America (NOTARO et al., 2013; SILVA, 2013; FRAIRE SON; BAHIA, 2015).

In $2013,281,718,000$ tons of cassava were produced worldwide, with Brazil being the fourth largest producer in the world with $23,977,757$ tons, behind Nigeria, Indonesia and Thailand. The north and northeast regions of Brazil have a large volume of production and cultivated area is in the south, southeast and midwest, the ones with the highest agricultural yield. The State of Pará is the largest national producer of cassava root, followed by Paraná, Maranhão and Bahia (IBGE, 2015).

In Alagoas, the regions that stand out as cassava producers are the wild, with $70 \%$ of the total production of the state (Arapiraca, São Sebastião and Campo Alegre), the forest zone and the north coast, being the first region, the one with the largest number of producers, responsible for 13.36 t.ha- $^{-1}$ and 240.448 tons, occupying the second place in productivity when compared to the other states of the northeast (CONAB 2013).

Notaro (2012) emphasized that this crop is still family farming and develops in a rudimentary way, and the main means of propagation is vegetative and varieties of low genetic quality are still cultivated. Its usefulness is associated with the content of hydrocyanic acid (HCN) present in leaves and roots, which classifies it as meek or sweet (<180 mg kg-1 de $\mathrm{HCN}$ ) also known as "macaxeira", used for fresh consumption; intermediate $\left(180-300 \mathrm{mg} \mathrm{kg}^{-1}\right)$ and bitter or angry (>300 mg kg-1) these last two are used for animal feed, starch production, flour and biofuel (OLIVEIRA et al., 2012).

The greatest utility of cassava is in the food industry, mainly in the production of starch destined for the modified starch market, which in addition to serving regional cuisine in breads, tapiocas, beijus, gum cake and tomboy's foot; is one of the products derived from the plant that employs more labor and adds a high value in the processed product, according to Nascimento Júnior (2015). Regarding the use for the extraction of 
fermented products in the biofuel industry, cassava has been shown to be a good alternative in the manufacture of ethanol, as it presented a lower energy cost in production, comparing sugarcane and corn, according to Salla et al., (2010).

According to Alves (2006), the phenology of cassava can vary from 6 to 24 months of cultivation, but commercially it is 12 to 18 months for the processing of flour and starch and between 8 and 10 months for table. Among the varieties planted in Alagoas, rosinha stands out, whose cycle varies between 9 and 10 months in dry land, and can be anticipated for 7 to 8 months under irrigated system conditions. This variety can reach three meters in height, maintains the plant stand at the end of the crop with good production of branches and productivity in $21 \mathrm{t} \mathrm{ha}^{-1}$ (DINIZ et al., 2009).

Nascimento Júnior (2015), reports in his work that even with the rusticity of the crop is necessary is attentive to the adafo-climatic conditions, stating that cassava produces well in fertile soils, with $\mathrm{pH}$ between 5.5 to 7.0 with sandy or medium textural class and good natural drainage. The ideal climatic condition is in the temperature range between $20^{\circ} \mathrm{C}$ and $27^{\circ} \mathrm{C}$, and can be established in environments with temperatures between $16{ }^{\circ} \mathrm{C}$ and $38^{\circ} \mathrm{C}$; with precipitation between 1000 and $1500 \mathrm{~mm}$ year -1 , in semi-arid regions between 500 and $700 \mathrm{~mm}^{\text {year- }}{ }^{-1}$; altitudes of 600 to 800 meters above sea level and light period of 12 hours day-1 (SILVA; ANDRADE, 2011; SILVA, 2013).

\subsection{DISEASES IN CASSAVA CROP}

Several factors can limit cassava production, such as the occurrence of insect pests and disease-causing phytopathogens, impairing the quality and development of the crop in Brazil and worldwide. According to Nascimento Júnior (2015), cassava is susceptible to several phytopathogens and this causes severe economic losses in production.

Among the diseases of importance stand out the causes of leaf lesions such as brown spot (Cercosporidium henningsii) white spot (Phaeoramularia manihotis), burning leaves (Cercospora vicosae), black spot (C. manihobaea) and anthracnose (Colletotrichum gloeosporioides f.sp. manihotis) that limit photoassimilates (SILVA; 
ANDRADE, 2011; MORAIS et al., 2013; OLIVEIRA et al., 2013). And root rot, caused by fungi and oomicetes, such as Lasiodiplodia sp., Pythium sp., Rosellinia sp., Fusarium sp., Neoscytalidium lignicola, Phytophthora drechsleri Tucker however, the last three phytopathogens are the most frequently involved in root rot in the state of Alagoas (Figure 1) and in most producing regions. Information on the rot of cassava roots is still incipient and is of paramount importance to serve as a tool in decision making on the best strategy to use (MASSOLA JR; BEDENDO, 2005; MUNIZ et al., 2006; NOTARO et al., 2013; SILVA, 2013; FUKUDA, I'M NOT GOING TO BE OTSUBO, 2015).

Notaro et al., (2013) and Silva (2013) warn about the high socioeconomic impacts caused by cassava root rot in the states of Maranhão, Pará, Alagoas and Pernambuco, as it is causing significant losses in productivity, in addition to making the areas unviable for planting throughout the crop cycles. According to Nascimento Júnior (2015), being Omyceto Phytophthora sp and the fungus Fusarium sp., are main pathogens of culture in the Northeast and cause losses ranging from 30 and $70 \%$. The author also states that under favorable conditions the disease can cause $100 \%$ loss. 
Figure 1. Aspect of colonies and reproductive structures of phytopathogens-causing cassava rot isolates in the State of Alagoas: Fusarium sp. (A1-A6), Neoscytalidium sp. (B1-B6) and Phytophthora sp. (C1-C6). Colony of Fusarium sp. (A1); conidia (A2); conidiogenic cell (A3-A6). Neoscytalidium sp. colony (B1); Conidia (B2-B6). Phytophthora sp colony (C1); Spomangio (C2); Chlamydospores (C3 and C4); Spomangios (C5) and Sporantia in reproduction (C6).

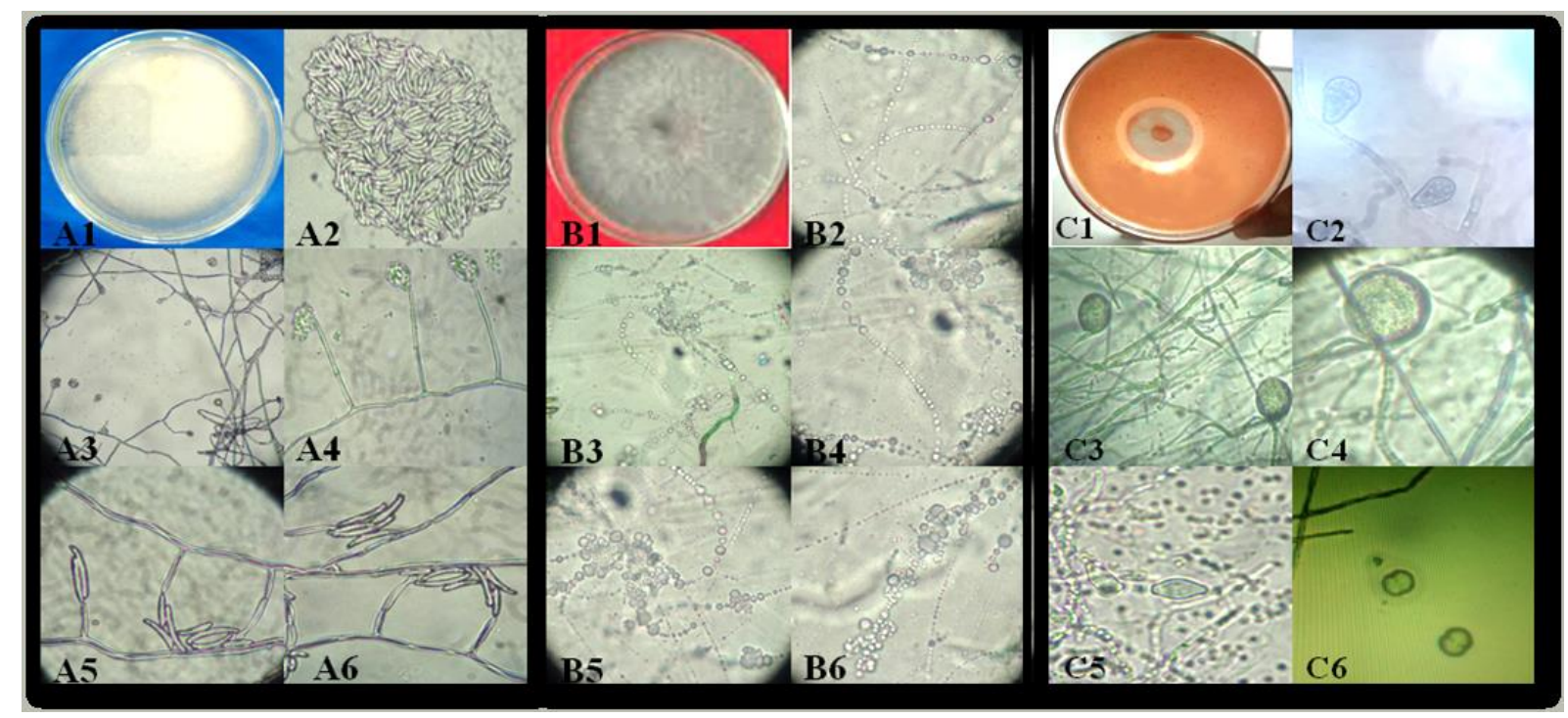

Fonte: SILVA e NASCIMENTO JÚNIOR (2016).

The rot caused by Fusarium sp., occurs in young and adult plants, with symptoms of sudden wilting and severe defoliation, which can be potentiated in areas of clayey and poorly drained soil (SILVA; TEXEIRA, 2012). This fact has already been reported by Gomes; Leal (2003), who when working with cassava in the states of Sergipe, Bahia and Alagoas, states that root rot is the most limiting disease of culture in the Northeast region, especially when it is implanted in areas formed by compacted soil.

The phytopathogens causing the rot have distinct symptoms. The authors report that phytophthora sp. usually attacks adult plants, causing "soft" rot in the roots, with very strong odor, similar to that of decaying organic matter and grayish coloration. The appearance of signs are more frequent and visible in the roots, but there are reports of the existence of young people presenting symptoms at the base of the stems of newly twinned plants, causing wilting and total death. In the case of dry rot caused by 
Fusarium sp., direct root damage rarely occurs, but the problem is accentuated at any stage of plant development. (GOMES; LEAL, 2003; SILVA; TEXEIRA, 2012; NASCIMENTO JÚNIOR, 2015).

\subsection{THE PHYTOPATHOGEN FUSARIUM}

The genus Fusarium was described in 1809 by Link. The representatives of this genus belong to the kingdom Fungi, phylum Ascomycota, classes Eauscomycetes and Pyrenomycetes, order Hypocreales, presenting 65 species, 55 varieties and 22 special forms, according to Wollenweber; Reinking (1935)1 quoted by Ventura (1999). It is one of the most important phytopathogens in the world, with wide geographical distribution, distributed in the soil and in association with plants. Having cosmopolitan and other species with occurrence restricted to certain environments (VENTURA, 1999). Most species are saprobic, but there are representatives of the Fusarium complex that produce mycotoxins that can affect human and animal health (URBEN et al. 2009). Seifert (2006); Querales (2010) report that the genus Fusarium is a complex group growing in number of species and generate taxonomic controversies for phytopathologists.

Milanesi (2009), comments that Fusarium sp., can occur especially in places of tropical and subtropical climates, and has a great ability to survive for long periods in the soil outside its hosts, through the formation of resistance structures called chlamydospores. Three groups within the genus are the most specific examples of these changes, named after the teleomorph group of the Gibberella fujikuroi (Sawada) Wollenw complex, the Fusarium solani (Mart.) Sacc., and F. graminearum complex.

The genus may present colonies of colors ranging from violet, dark purpura to orange, but the predominance is of pale colony of rapid growth, airy and diffuse mycelium (MARTINS, 2005). Puhalla (1981); Martins (2005); Agrios (2005), report that conidia structures (micro and macro), morphology, disposition, variety of conidiophores and chlamydospores were the basis for identification of Fusarium sp species. Classical taxonomists describe the presence of single-celled and uninucleated microconidia and frequent multicellular macroconidia with cell with only one nucleus as genetically 
identical progenitor. The sexual stages of Fusarium are ascomycetes; the sexual spore is the ascospore. Those allocated in the genus Nectria have bicellular ascospores.

Each cell of the bicellular ascopore is uninucleated and both nuclei are genetically identical. Others, as is the case in Gibberella, form multicellular ascospores. Martins (2005) mentions that morphological characteristics are influenced by the environment and nutrition, so culture media are used to select microorganisms and group them, based on the nutritional needs that are made available in the culture environment under standardized conditions to identify them. Due to this plasticity and variations in phenotypic characteristics found in this fungus, taxonomy based only on morphological concepts is not reliable. (MARTINS, 2005; URBENS et al., 2009; QUERALES, 2010).

The identification of fusarium species is one of the first steps for its study. Traditionally it has been carried out on the basis of morphology, since the publication of the treatise of the genus "Die Fusarien" in 1935 by Wollenweber; Reinking ${ }^{1}$. Other systems were proposed, but did not solve the problem of species identification. The tools for identification were increased and include the use of optical and electronic microscopy, selective and differential means, enzymatic comparisons, secondary metabolites, as well as the use of immunological and molecular technologies (LEAL-BERTIOLI, 1998; MARTINS 2005). O'Donnell et al., (2000); Summerell et al., (2003); Ottoni, (2008); comment that with the advent of molecular tools the identification of Fusarium is based on the morphology, biology and characteristic of the species, based on sexual compatibility, phylogeny and sequences of genomic regions.

For decades, classical identification uses morphological characteristics as a basis, but has generated controversy, because several taxonomists and phytopathologists find it necessary to use other models to separate the species, while others believe that these models affect the taxonomy of the genus. It is noteworthy that practice in the diagnosis of causal agents of diseases in planting the adoption of genetic models are more adapted to the studies conducted by mycologists. Nevertheless, these changes are relevant, since in a genus there may be very close species and this can lead to a misdiagnoses with important practical consequences (QUERALES, 2010). 
According to Notaro et al. (2013), Fusarium solani Math (Sacc) is the species that prevalent causes root rot in cassava cv branquinha in the State of Pernambuco. This species produces, in culture medium, aerial mycelium, with color ranging from white to cream, becoming bluish-brown when sporodochios are present. It produces three types of asexual spores: the slece-shaped macroconidia, with approximate dimensions of 15-35 x 4-7 $\mu \mathrm{m}$ with 3-5 septa; microconidia, which have or do not septum, measure about 5-10 x 1-3 $\mu \mathrm{m}$ and chlamydospores, which are hyaline, globose, smooth to rough, measuring $6-10 \mu \mathrm{m}$.

The sexual state of the fungus is Nectria haematococca (Ascomycete). This fungus survives on infected cultural remains, soil, tubers and seeds, and may persist for several years. The ideal conditions for your establishment are temperatures ranging from 15 to $25{ }^{\circ} \mathrm{C}$, humidity of 50 to $75 \%$, occurrence of injuries, planting in contaminated soils and inadequate storage. Injuries to the root system, especially those caused by nematodes, facilitate the penetration of the fungus into the roots of the hosts.

\subsection{DISEASE CONTROL}

Because it is a pathogen carried by the soil, its elimination after installation in the planting area becomes a very difficult task and chemical control measures practically do not exist, except for preventive ones, such as the use of seed treatment or other propagation materials (LAZAROTTO et al., 2012). The cultural control, based on the prevention of injuries during harvest and storage, the use of healthy seeds and substrate free of the pathogen, used only once, the balanced application of nutrients, efficiency in irrigation, as well as varieties that present resistance characteristics and the treatment of cuttings (maniva) and substrate with fungicide for sowing when infected, can minimize production losses.

As a control measure, the most efficient measure was based on research conducted in the Northeast by Embrapa Cassava and Fruit And Agricultural Development Company (EMAGRO), was the use of tolerant variety (Osso Duro, Cedinha, Bibiana, clone 148/02, Aramaris and Kiriris), associated with crop rotation and planting system, 
which reduced rot by about 80\% (GOMES; LEAL, 2003; BETTIOL, 2009; LOBO JÚNIOR et al., 2009; LAZAROTTO et al., 2012).

For the control of Fusarium sp., the chemical difenochonazol and thiram, in the treatment of soil and seeds, are the most recommended due to the efficiency presented. However, chemical control has become constant and with the indiscriminate use ecological problems have arisen, as these cause changes in the environment favoring phytopathogens with resistance due to selective pressure, emergence of secondary outbreaks, reduction of the population of beneficial microorganisms, due to the deposit of resid that accumulates in the soil, water and food making them harmful, with deleterious effect to animals and humans (BIZI , 2015).

In general, the high costs of the practice of chemical control, associated with the emergence of resistance to commonly used products, as well as the prohibition of methyl bromide, makes it essential to develop alternative control techniques (BETTIOL, 2009; LOBO JÚNIOR et al., 2009; LAZAROTTO et al., 2012). For the biological, plant resistance induction is a promising alternative, as it uses natural extracts with microbial and/or inducing properties (MORAES, 1992; STANGARLIN et al., 2008).

\subsection{BIOCONTROL OF PHYTOPATHOGENS}

The attempt to reduce the deleterious actions of a pathogen or inoculum has been a constant in agriculture, and the substitution of agrochemicals by natural products with suppression or control activity has been one of the viable alternatives, because the residue left is more quickly assimilated and decomposed by the environment due to its low persistence (SOUZA, 2013; BIZI, 2015).

Ethur, (2006) and Dianese, (2007); report the importance of research in the area of biological control, such as the introduction of antagonistic organisms in environments where the pathogen is causing damage. Cancela (2015), states that the dynamics of the action of biological control occurs in a natural way and consists in the regulation of the number of plants and animals by natural enemies. This strategy is a fundamental 
part of the balance of nature and how chemical control has advantages and disadvantages. Among the advantages is the fact that it is a non-toxic measure, does not cause imbalance, has no contraindications, provides an extensive and efficient control when there is no chemical control, because it will need more technology due to its slow effect, difficult to acquire and can not always be applied at any time of the year.

Maintaining balance in the Agroecosystem is a practice of biological control so that the pathosystem does not cause significant damage in the biocontrolling action of nonpathogenic organisms of the system. The authors also report that disease is more than a pathogen/host interaction relationship, because the influence of the environment and also a diversity of non-pathogenic organism rests at the site of infection may limit or increase the pathogen's aggressiveness, or host resistance. Thus, pathogen, host and antagonist interact with each other in the components of biological control (BIZI, 2015; CANCELS 2015).

A limiting factor for the use of biological products is the availability in the market for this control modality. Another problem is that many natural products are not properly registered for use on a commercial scale (SILVA et al., 2008). The presence of the phytopathogen interferes with plant homeostasis, but it can also act by triggering defense mechanisms and/or activating genes that confer resistance of the host plant (AGRIOS, 2005). Michereff et al., (1993), state that the pathogen has determining activities involving growth, infectivity, aggressiveness, virulence and other attributions of the pathogen or processes, which determine infection, development of symptoms and reproduction. The interaction between antagonist, host and pathogen does not occur in a particular way, but mutually.

Several authors have already described the ability of biocontrangers to interact and interfere in the development of the phytopathogen by mechanisms of action such as competition for space and nutrients to antibiosis, mycoparasitism or hyperparasitism, predation, induction of resistance, thus increasing competitive advantage in the environment. These mechanisms vary from species to species and also from lineage to lineage within the same species, according to host-parasite interaction. (CARVALHO, 2006; BETTIOL; MORANDI, 2009; BRITO et al., 2010; ZUCCHI, 2010; 
DIAS, 2011; MACHADO et al., 2012; BIZI, 2015; CANCELA, 2015; FIPKE, et al., 2015).

Many microorganisms have presented high biocontroller potential and the genus Trichoderma Pers. has been used in several studies. T. hamatum (Bonord.) Bainier, T. viride Pers., T. aureoviride Rifai, T. harzianum Rifai, T. koningii Oudem, $T$. pseudokoningii Rifai and T. longibrachiatum Rifai are the most cited (BETTIOL; GHINI, 2005). Ezziyyani et al., (2007) report that the frequency of Trichoderma spp., is due to its versatility either by competition, hyperparasitism and antibiosis to phytopathogens such as Phytophthora, Fusarium and Neoscytalidium. Remuska \& Pria (2007) evaluating the antagonistic effect of Trichoderma spp., in the control of mycelial growth of phytopathogenic fungi observed that this exerted antagonism on some root phytopathogens, such as Sclerotium rolfsii, Pythium aphanidermatum and Fusarium solani, the latter genus being described as one of the main phytopathogens associated with cassava root rot in the state of Pernambuco.

Hoffmann et al., (2015) reported that they had $80 \%$ control of Fusarium sp., using Trichoderma spp isolates. Da Silva et al., (2011); Pereira (2013) proved in his works a great level of inhibition of mycelial growth of $F$. solani by Trichoderma spp species. Souza et al., (2015) also had promising results with Fusarium sp., and Bipolaris sp., using the same biocontroller. Other studies by Bomfim et al., (2010); Dias (2011); Lazarotto et al., (2012); Santos et al., (2012); Marques et al., (2014), obtained promising results presenting good to excellent performance, with regard to inhibition of mycelial growth of phytopathogens tested by them.

\subsection{TRICHODERMA BIOCONTROL STRATEGIES}

The genus Trichoderma, belonging to the Fungi Kingdom, phylum Ascomycota, classes Eauscomycetes and Pyrenomycetes, order Hypocreales, family Hypocreaceae, genus Hypocrea (teleomorph). This fungus has great antagonistic potential and is often associated with suppressive soils. (MELO, 1991). According to Harman et al. (2004); Harman (2005), its use can offer other advantages: 
decomposition of organic matter, competition with a deleterious microflora through the colonization of the rhizosphere, production of antibiosis and induction of resistance.

Trichoderma species have already been documented for the control of various pathogens, such as Rhizoctonia solani Kühn, Sclerotium rolfsii Sacc., Sclerotina sclerotiorum (Lib.) by Bary, Fusarium spp. e Pythium spp. (MELO; AZEVEDO, 1998). Numerous species of Trichoderma, including $\mathrm{T}$. harzianum Hifai, showed a high rate of parasitism and antagonistic activity for phytopathogens such as S. rolfs ii, S. minor and S. sclerotiorum, R. solani and Pyricularia grisea Sacc. (ROLLAN et al., 1999; RONDÓN et al., 2007).

According to Dos Santos (2010), the isolate of $T$. harzianum presented in vitro antagonism over the fungus S. rolfsii; being able to hyperparasitize the hyphae of the pathogen and compete for space and nutrient. Silva et al. (2013), working with isolates of Trichodema spp., as biological control agent of S. lignicola, observed that initially the isolate of Neoscytalidium sp. it was very promising when confronted with Trichoderma spp., but when they were found in the Petri dish, Trichoderma spp., superimposed the pathogen colony. By observing the region where the antagonist overlaps to phytopathogens, it was possible to notice a degradation of the hyphae of the pathogen by enzymatic action, since it was accurately distinguished only spores and hyphae from the antagonist.

For Robbs (1992) and Barbosa; Meza (2009) the competition for food and antibiosis, are the mechanisms most frequently used by biocontrol agents, since reproduction and rapid colonization are attributes of organisms that use the available resources more efficiently and quickly, ensuring their survival. According to Ethur (2006), the competition is one of the main strategies of trichoderma sp. isolates, for this fact they are used as biocontrollers.

The secretion of organic antibiotic substances (antibiosis), produced by microorganisms, which even in low concentration interfere in metabolic activities, inhibition or stoppage of growth and sporulation, reduction in spores germination, and distortions in hyphae and endolysis, whether specific or broad-aspected, are important 
devices for the efficiency of antagonist organisms (LOBO JUNIOR; ABREU, 2000; BOMFIM, 2007; SOUZA, 2013). According to Claydon et al., (1987), antibiotics are products of secondary metabolism of their producers, and may be more important in inhibiting other organisms than competition for nutrients. Antibiosis has also been reported by several researchers as one of the mechanisms of action of Trichoderma species (BETTIOL, 1991; DIAS, 2011; CARVALHO FILHO, 2013). Gliotoxin, viridine and trichodermine are some of the substances produced by Trichoderma species capable of inhibiting the development of other fungi (Amorim et al., 2011). Ethur (2006) reported that gliotoxin was responsible for inhibiting the germination of spomangios and mycelial growth of Pythium ultimum.

According to Bomfim et al., (2010) and Souza (2013), the biocontroller will be successful if it is able to degrade the cell wall (composed of carbohydrates, such as chitin), as well as proteins and lipids in significant amounts of the phytopathogen or interrupt the processes related to its synthesis. Therefore, the production of enzymes that hydrolyze the cell wall components of phytopathogens, particularly chitinases and glucanases, is a common feature in many biocontrol agents. Some representatives of the son-in-law Trichoderma are cited in works as an excellent producer of cellulase and chitinases, enzymes that degrade cellulose and chitin (MELO, 1991; HARMAN et al., 2004).

Mycoparasitism, a situation in which the antagonist microorganism lives on or within the antagonized fungus, feeding and developing at its expense, is another important mechanism of action as an attribute of a good biocontroller. Mycoparasitism involves antibiosis and cannibalism caused by the action of hydrolytic enzymes, such as chitinases, glucanases, proteases and lipases, which cause the death of one of them that thus serves as food for the survivor (LOBO JUNIOR; ABREU, 2000; HARMAN, 2000; BOMFIM, 2007; BARRA et al., 2008; ZUCCHI, 2010).

Chitinases and $\beta$-1,3-glucanases are directly involved in the interactions of mycoparasitism between Trichoderma species and their hosts, due to the majority of phytopathogenic fungi possessing in their chitin cell wall, organized in regularly ordered layers and $\beta-1,3-g l u c a n s$ arranged as a filling in amorphous manner. Chitinase 
acts randomly and degrades the biological structures and components of fungal cells, releasing oligomers that induce exoquitinases, thus beginning the mycoparasitic attack, hydrolyzing the oligosaccharides of the phytopathogen cell wall. (GIESE et al., 2003; MARCELLO, 2008; BAUERMEISTER et al., 2010).

Melo (1996) reports that necrotrophic mycoparasitism is efficient in antagonism to phytopathogens, especially those with resistance structures considered difficult to be attacked by microorganisms, such as spros, sclerotia, chlamydospores and microsclerotia. Melo, melo. Azevedo (1998) states that Trichoderma sp. it has mycoparasite characteristics, because they can locate and detect phytopathogens, possibly by biochemical stimuli, grow towards hyphae of susceptible fungi, and when they come into contact, they form structures such as appressoriums, curl up, to their full extent, penetrate and digest them. The genus Trichoderma is undoubtedly an excellent microbial control agent, because it presents, in addition to the skills described above, essential characteristics, being: environmental impact and low or null, easy propagation (SPIEGEL; CHET, 1998), ability to survive in unfavorable environments, besides containing populations of pathogens living in the soil (VINALE et al., 2008).

\section{FINAL CONSIDERATIONS}

Interspecific ecological relations are events that occur at various levels in nature and are mostly made of demmonic forms, in the condition of relationship between microorganisms being competition, antibiosis and parasitism the most frequent. Thus disease-causing microorganisms in plants not only cause economic losses but evolve simultaneously, thus causing damage from the initial stage of crop development. Traditional methods of phytopathogen control have been used, the application of chemical pesticides and fungicides, has also been a very frequent form that cause major problems due to environmental impacts.

One of the most promising ways to achieve a reduction in the use of these agrochemicals, or even a future substitution, biological control through the numerous biocontrollers such as fungi of the genus Trichoderma that are efficient and do not cause destructive environmental impacts. 


\section{REFERENCES}

AGRIOS, G.N. Plant pathology. Amsterdam : Elsevier Academic Press. 5.ed, 2005. 922p.

ALVES, A., A., C.. Fisiologia da mandioca. In: Aspectos socioeconômicos e agronômicos da mandioca. EMBRAPA Mandioca e Fruticultura Tropical, Cruz das Almas, 2006., 817p.

AMORIM, L.; REZENDE, J. A. M.; BERGAMIN FILHO, A. Manual de Fitopatologia. Piracicaba: Agronômica Ceres. v. 1,4. Ed, p. 383 -387, 2011.

BARBOSA, R.J.F.; MEZA, C.L.S. Antagonismo in vitro de Trichoderma harzianum rifai sobre Fusarium oxysporum schlecht $f$. sp passiflorae en maracuyá (Passiflora edulis sims var. flavicarpa) del municipio zona bananera colombiana. Rev. Fac. Nal. Agr. Medellín, v.62, n.1, p.4743-4748, 2009.

BARRA, V. R.; ROMEIRO, R.S.; FERRAZ, H.G.M.; MACAGNAN, D.; SILVA, H. S. A.; MOURA, A. B.; HALFELD-VIEIRA, B. A; MENDONÇA, H. L.; VIEIRA JÚNIOR, J. R. Potencialidade antagonística em alguns procariotas agentes de biocontrole de enfermidades de plantas. Ver. Summa Phytopathologica, v.34, n.2, p.121-126, 2008.

BAUERMEISTER, A.; REZENDE, M. I.; GIESE, E. C.; DEKKER, R. F. H.; BARBOSA, A. M. 1,3-Glucanases Fúngicas: produção e aplicações biotecnológicas. LONDRINA SP. rev. Semina: Ciências Exatas e Tecnológicas, , v. 31, n. 2, p. 75-86, jul./dez. 2010. http://www.uel.br/seer/index.php/semexatas/article/view/5249

BETTIOL, W. Controle biológico de doencas do filoplano. In: BETTIOL, W., org. Controle biológico de doencas de plantas. Jaguariuna: EMBRAPA-CNPDA, 1991. p.33-52 (EMBRAPA-CNPDA. Documentos, 15).

BETTIOL, W.: MORANDI, M.A.B. Controle Biológico de Doenças de Plantas no Brasil. In: BETTIOL, W.: MORANDI, M.A.B. (Org). Biocontrole de Doenças de Plantas: uso e perspectivas. Jaguariúna - SP: Embrapa Meio Ambiente, p. 7-14, 2009. 
BETTIOL, W.; GHINI, R. Solos Supressivos. In: MICHEREFF,S. J.; ANDRADE, D. E. G. T.; MENEZES, M. (Eds.) Ecologia e Manejo de patógenos radiculares em solos tropicais. Recife:UFRPE, Imprensa Universitária, 2005. cap.6, p. 125-143.

BIZI, R. M., Utilização de fungos no Controle Biológico de Doenças. < http://www.floresta.ufpr.br/alias/lpt/public_html/contbio03.html.> Acesso em 16/11/2015.

BOMFIM, M. P., Antagonismo in vitro e in vivo de Trichoderma spp. a Rhizopus stolonifer em maracujazeiro amarelo. Vitória da Conquista BA, 2007. 74f.: Dissertação de Mestrado. Universidade Estadual do Sudoeste da Bahia. 2007

BOMFIM, M. P., SÃO JOSÉ, A. R., REBOUÇAS, T. N. H., ALMEIDA, S. S. D., SOUZA, I. V. B., \& DIAS, N. O . Avaliação antagônica in vitro e in vivo de Trichoderma spp. a Rhizopusstolonifer em maracujazeiro amarelo. Summa Phytopathologyca, v.36, n.1, p. 61-67, 2010.

BRITO, F. S.; MILLER, P. R. M., STADNIK, M. Presença de Trichoderma spp em composto e suas características para o controle de fitopatógenos. Revista. Bras. de Agroecologia, Porto Alegre , p. 43-53. 2010.

CANCELA, K. C., Controle Biológico Florestal Conceitos, Terminologia, Descrição e Caracterização de Agente. Proteção florestal Disponível em $<$ http://www.floresta.ufpr.br/alias/pf/public_html/contbio01.html> Acesso em 16/11/2015.

CARVALHO FILHO, M. R., Relações filogenéticas, identificação e potencial de uso de isolados de Trichoderma no controle do mofo branco e como promotores de crescimento do feijoeiro. Brasília-DF, 2013. 123f. Tese de Doutorado. Programa de Pós-graduação em Fitopatologia, Universidade de Brasília. Brasília. 2013.

CARVALHO, A. C., Bioprospecção de isolados de Trichoderma stromaticum para o controle biológico da Vassoura-de-Bruxa do Cacaueiro. 2006. 82f. Dissertação de Mestrado. Universidade Estadual de Santa Cruz. 2006. 
CONAB- CLAYDON, N.; ALLAN, M.; ITANSON, J.R.; AVENT, A. G. Antifungal alkyl pyrones of Trichoderma harzianum. Transactions of the British Mycological Society, v.88, p.503-513, 1987. COMPANHIA NACIONAL DE ABASTECIMENTO. Perspectivas para a agropecuária. Conab, Brasília , v.1, 2013., 154p.

DA SILVA, D. C. V., TIAGO, P. V., \& DE SOUZA-MOTTA, C. M. . Isolamento e seleção de fungos filamentosos do solo de sistemas agroflorestais do Município de Bom Jardim (PE) com base na capacidade de produção de enzimas hidrolíticas1. Revista Brasil. Bot, 34(4), 607-610. 2011

DIANESE, A. de C. Variabilidade e controle de Phytophthora palmivora (Podridão-do-pé) e controle da varíola (Aperisporium caricae) do mamoeiro (Carica papaya). 2007. 109f. Tese Doutorado - Universidade de Brasília, Brasília. 2007

DIAS, P. P., Controle biológico de fitopatógenos de solo por meio de isolados de fungos do gênero Trichoderma e sua contribuição no crescimento de plantas. 2011. 101 f. Tese Doutorado. Universidade Federal Rural do Rio de Janeiro. Seropédica - Rio de Janeiro. 2011

DINIZ, M. de S.. Efeito da manipueira na adubação da mandioca. Revista Raízes e Amidos Tropicais, v. 5, 2009.

DOS SANTOS, J. et al. Atividade hiperparasíticade Trichoderma spp. sobre escleródios de Sclerotinia sclerotiorum em solo. In: SEMINÁRIO DE INICIAÇÃO CIENTÍFICA

TECNOLÓGICA,7,2010.Anais...EPAMIG,2010.Online.Disponívelem:http://www.epa mig.br/index.phpoption=com_docman\&task=cat_view\&gid=121\&dir=DESC\&order=da te\&limit=10\&limitstart=10.Acesso em Dezembro 2015

ETHUR, L.Z. Dinâmica populacional e ação de Trichoderma no controle de fusariose em mudas de tomateiro e pepino. 2006. 154p. Tese (Doutorado em Fitopatologia) - Universidade Federal de Santa Maria, Santa Maria-RS. 2006. 
EZZIYYANI, M.; REQUENA, M. E.; EGEA-GILABERT, C.; CANDELA, M. E. Biological Control of Phytophthora Root Rot of Pepper Using Trichoderma harzianum and Streptomyces rochei in Combination. Journal of Phytopathology , [S.I], v.155, n.6, p. 342-349, 2007

FAO. Faostatidtics Database. Disponivel em $<$ https://www.fao.org.br/FAO_Brf2mpu3a.asp> Acesso em Dezembro de 2015.

FIPKE, G. M; PAZINI, J.B.; ETHU,L. Z. Antagonismo de isolados de Trichoderma spp. ao Sclerotinia sclerotiorum em diferentes temperaturas. Magistra, Cruz das Almas BA, V. 27, N.1, p. 23 - 32, Jan./Mar. 2015

FUKUDA C.; OTSUBO A.A. Cultivo da mandioca na região centro sul do Brasil. Embrapa Mandioca e Fruticultura. HTTP://sistemasdeproducao.cnptia.embrapa.br/FontesHTML/Mandioca/mandioca_c entrosul/doenc s.htm . Acessado em 16 de julho de 2015.

FRAIFE FILHO G. A., BAHIA J. J. S., Mandioca. Ceplac-Cepec-BA. http://www.ceplac.gov.br/radar/mandioca.htm . Acessado Dezembro de 2015.

GIESE, E. C.; BARBOSA, A. M.; SILVA M.L.C. Glucanases Fúngica: Produção e aplicações das -1,3 e -1,6 glucanases. Revista Biotecnologia Ciência e Desenvolvimento, Brasília-DF, oㅜ 30 , P.97-104.. jan/jun 2003.

GOMES, J. C.; LEAL, E. C., Cultivo da Mandioca para a Região dos Tabuleiros Costeiros. In.: Podridão Radicular. Embrapa Mandioca e Fruticultura. Sistemas de Produção, 11. ISSN 1678-8796 Versão eletrônica/Jan/2003. https://sistemasdeproducao.cnptia.embrapa.br/FontesHTML/Mandioca/mandioca_ta bcosteiros/doencas.htm . Acesso 13/12/2015.

HOFFMANN, C. A. et al.. Potencial de antagonismo de isolados de Trichoderma sp. contra o isolados de Fusarium sp., in vitro. Revista Verde de Agroecologia e Desenvolvimento Sustentável, v. 10, n. 1, p. 236-242, 2015. 
HARMAN, G. E. The Nature and Application of Biocontrol Microbes II: Trichoderma spp. Overview of Mechanisms and Uses of Trichoderma spp. Phytopathology, St Paul, v. 96, p. 190-194. 2005

HARMAN, G. E. Myth and dogmas of biocontrol changes in perceptions derived from research on Trichoderma harzianum T-22. Plant Disease, St. Paul, v. 84, p.377-393, 2000.

HARMAN, G.E. HOWELL, C. R., VITERBO, A., CHET, I., \& LORITO, M. Trichoderma species-opportunistic, avirulent plant symbionts. Nature Reviews Microbiology. V.2, p. 43-56. 2004.

IBGE - Instituto Brasileiro de Geografia e estatística. PAS - Pesquisa Anual de Serviços, 2015. [online]Disponível na internet via WWW URL: http://www.ibge.gov.br/home/. Arquivo consultado Dezembro de 2015.

LAZAROTTO, M.; BOVOLINI, M. P.; MACIEL, C. G.; MUNIZ, M. F. B. Seleção in vitro de Isolados de Trichoderma spp. com Potencial de Antagonismo a Isolados Patogênicos de Fusarium spp. In: XVI Simpósio De Ensino, Pesquisa E Extensão, Unifra, v. 3, 2012.

LEAL- BERTIOLI, S. C. DE M. O enfoque molecular na sistemática de fungos. Revisão Anual de Patologia de Plantas. V.6. p. 197-230, 1998

LOBO JÚNIOR, M. e ABREU, M.S. Inibição do crescimento micelial de Sclerotinia sclerotiorum por metabólitos voláteis produzidos por alguns antagonistas em diferentes temperaturas e pH's. Ciência Agrotécnica, Lavras, v.24, p.521-526, 2000.

LOBO JUNIOR, M.; BRANDÃO, R. S.; CORRÊA, C. A.; GÖRGEN, C. A.; CIVARDI, E. A.; OLIVEIRA, P. de. Uso de braquiárias para o manejo de doenças causadas por patógenos habitantes do solo.Santo Antônio de Goiás: Embrapa Arroz e Feijão, 2009. 8 p. (Embrapa Arroz e Feijão. Comunicado técnico, 183). 
MACHADO, D. F. M.; PARZIANELLO, F. R.; SILVA, A. C.F. e ANTONIOLLI, Z. I. Trichoderma no Brasil: o fungo e o bioagente. Revista de Ciências Agrárias, v.35, n.1, p. 274-288, 2012.

MARCELLO, C. M. Avaliação da expressão e caracterização de uma exo-b-1,3glucanase envolvida no mecanismo de micoparasitismo de Trichoderma asperellum. Brasília-DF, 2008. 89f. Tese de Doutorado. Laboratório de Enzimologia Departamento de Biologia Celular do Instituto de Biologia da Universidade de Brasília - UnB. Brasília - DF. 2008.

MARQUES, H. I. P.; SILVA, M. B.; MARQUES, M. D. P.; RODRIGUES, R. C.; RIBEIRO, P. R. C. C. Inibição do crescimento micelial de Trichoderma harzianum por fertilizantes líquidos. Enciclopédia Biosfera, v. 10, n. 18, p. 2040, 2014.

MARTINS, M. K.. Variabilidade genética de isolados de Fusarium spp. e estudo da interação com a planta hospedeira. 2005. 110f. Diss. Tese (Doutorado em Agronomia)-Escola Superior de Agricultura" Luiz de Queiroz", Universidade de São Paulo, SP.[Links], 2005

MASSOLA JR, N.S.; BEDENDO, I. P.. Doenças da mandioca. In: KIMATI, H. et al. Manual de fitopatologia: Doenças das plantas cultivadas;. 4ª Ed.vol. 2, p. 340-341 São Paulo: Agronômica Ceres, 2005

MELO, I. S. Potencialidades da utilização de Trichoderma spp. no controle biológico de doenças de plantas. In: BETTIOL, W. (Ed.). Controle biológico de doenças de plantas. Jaguariúna: CNPDA/EMBRAPA, 1991. p. 135-156.

MELO, I. S.; AZEVEDO, J. L. Ecologia Microbiana. Jaguariúna: Embrapa DNPMA, p. 393-419, 1998.

MELO, I.S. Trichoderma e Gliocladium como bioprotetores de plantas. Revis. Anu. Patol. Plantas v. 4, p. 261-295. 1996. 
MENEZES, J. P., LUPATINI, M., ANTONIOLLI, Z. I., BLUME, E., JUNGES, E., \& MANZONI, C. G. Variabilidade genética na região its do rDNA de isolados de trichoderma spp.(Biocontrolador) e Fusarium oxysporum f. sp. Chrysanthemi. Ciência e Agrotecnologia, 34(1), 132-139.2010

MICHEREFF, S.J.; MENEZES, M.; MARIANO, R.L.R. Potencial de Trichoderma para o controle da antracnose do sorgo. Fitopatologia Brasileira, Brasília, v. 18, p. 392-398, 1993.

MILANESI, P.M. Caracterização, toxicidade e patogenicidade de Fusarium spp. em genótipos de soja em sistema plantio direto. 2009. 91 p. Dissertação (Mestrado em Agronomia) - Universidade Federal de Santa Maria, Santa Maria, 2009.

MORAES, W. B. C. Controle alternativo de fitopatógenos. Pesquisa Agropecuária Brasileira, v. 27, n. 13, p. 175-190, 1992.

MORAIS, M. dos S.; NASCIMENTO, L. C do; MOREIRA, K. A.; SILVA, M. da; CAVALCANTI, N. T. D. O. Levantamento e avaliação da incidência das doenças da mandioca no estado da Paraíba. Summa Phytopathologica, v. 39, n. 3, p. 204. 2013.

MOURA, G. de M.; SILVA, M. D. O. da. Avaliação de resistência de cultivares de mandioca à podridão de raízes. Embrapa-CPAF/AC. Comunicado Técnico, 4p. Rio Branco 1997.

MUNIZ J. N, RUFFINO-NETTO A, YAMAMURA M, VILLA TCS, ARCENCIO R. Aspectos epidemiológicos da coinfecção tuberculose e vírus da imunodeficiência humana em Ribeirão Preto (SP), de 1998 a 2003. J. Bras. Pneumol., 32(6):529-34, 2006

NASCIMENTO JÚNIOR, N. A. Efeito da casca de mandioca no controle da podridão radicular causada por Phytophthora sp. em mandioca de mesa (Manihot esculenta Crantz) var. Rosinha em ambiente irrigado. Rio Largo- 
AL,2015.82f. Tese de Doutorado. (Programa de Pós-Graduação em Proteção de Plantas da Universidade Federal de Alagoas. Alagoas. 2015.

NOTARO, K. A. MEDEIROS, E. V., SILVA, C. A. D., \& Barros, J. A. Prospecção de fitopatógenos associados á podridão radicular da mandioca em Pernambuco, Brasil. Biosci. J., Uberlândia, v. 29, n. 5, p. 1832-1839, 2013.

NOTARO, K. A. Prospecção de fitopatógenos e caracterização de solos arenosos envolvidos na supressividade ou conducividade da podridão radicular da mandioca, causada por Neoscytalidium lignicola/ Krystal de Alcantara Notaro. Garanhuns-PE, 2012. 111f. Dissertação (PROGRAMA DE PÓS-GRADUAÇÃO EM PRODUÇÃO AGRÍCOLA). Universidade Federal Rural de Pernambuco - Unidade Acadêmica de Garanhuns, 2012.

O`DONNELL, K.; NIRENBERG, H.I.; AOKI, T.; CIGELNIK, E. A multigene phylogeny of the Gibberella fujikoroi species complex: detection of additional phylogenetically distinct species.Mycoscience, Tokyo, v. 41, p. 61-78, 2000.

OLIVEIRA, L. G. SILVA, A.C.S; SILVA, R. L. ,LIMA, D. W. S \& LIMA, G; COSTA. Atividade proteolítica de fungos de solo fitopatogênicos ao Feijão-Caupi [Vigna unguiculata (L.) Walp.] In: III CONAC Congresso Nacional de Feijão-Caupi. Pernambuco. Resumo expandido. 4p. 22-24 de abril Recife Pernambuco 2013.

OLIVEIRA, N. T; J. M. A., UCHÔA, S. C. P., RODRIGUES, G. S., MELVILLE, C. C., \& de ALBUQUERQUE, J. D. A. A.. Caracterização e identificação de clones de mandioca produzidas em Roraima para o consumo in natura. Revista Agro@mbiente On-line, v. 5, n. 3, p. 188-193, 2012.

OTTONI, R.J. Analise da incidência de Fusarium spp. toxigenicos e de níveis de fumonisinas em grãos ardidos de milho hibrido. 2008. 54 p. Dissertação (Mestrado em Microbiologia Agrícola) - Escola Superior de Agricultura "Luiz de Queiroz", Universidade de São Paulo, Piracicaba, 2008. 
PEREIRA, C O.F. Estudo da patogenicidade e controle biológico de Fusarium sp. Com Trichoderma sp. 2013.74f. Dissertação. Universidade de Caxias do Sul. 2013.

PUHALLA, J.E. Genetic considerations of the genus Fusarium. In: Nelson, P.E.; Toussoun, T.A.; Cook, R.J. (Ed) Fusarium: diseases, biology, and taxonomy. Pennsylvania: Pennsylvania State University, v.27, p.291-305, 1981.

QUERALES, P. J.. Caracterização morfológica e genética de Fusarium spp. isolados de sementes e associados à podridão do colmo de milho (Zea mays L.). Diss. Escola Superior de Agricultura "Luiz de Queiroz, 2010.

REMUSKA, A.C.; DELLA PRIA, M. Efeito de Bacillus truringiensis e Trichoderma sp. no crescimento de fungos fitopatogênicos. Publication UEPG: Ciências Exatas e da Terra, Agrárias e Engenharia, Ponta Grossa, v.13, n.3, p.31-36, 2007.

ROBBS, F. C. Controle Biológico de doenças em plantas. In: NETO, A. M. A.; BARAN, C. L. (ed.). Manual de Controle Biológico. Rio de Janeiro: Lidador. 1992. p.4651.

ROLLAN, MONACO C, NICO A. Efecto de la tempratura sobre la interaccion invitr o entre especies de Tricihoderma y Sclerotinia sclerotiorum, S. minor y Sclerotium rolfsii. Invest. Agr.: Prod. Prot. Veg. 14:1-16. 1999.

RONDÓN T.R, GUTIÉRREZ GR, ZAYAS A.D.P, PÉREZ LA, CUTIÑO Y.L. Efectividad in vitro de Trichoderma harzianum Rifai para el biocontrol de Rhizoctonia solani Kühn y Pyricularia Grisea sacc. aislados en el cultivo del arroz (Oryza sativa I.). Fitosanidad 11: 29-34.2007.

SALLA, D. A., CABELLO, C. Análise energética de sistemas de produção de etanol de mandioca, cana-de-açúcar e milho. Revista Energia na Agricultura. Botucatu, vol. 25, n.2, p.32-53., 2010.

SANTOS, C. C., OLIVEIRA, F. A. de; SANTOS, M. S. dos; TALAMINI, V.; FERREIRA, J. M. S.; SANTOS, F. J. dos., Influência de Trichoderma spp. sobre o crescimento 
micelial de Thielaviopsis paradoxa. Scientia Plena 8, 047309 www.scientiaplena.org.br . 2012

SEIFERT, K.A. Enhancing the relevance of fungal taxonomy to plant pathology: phylogenetics, molecular diagnostics, and long-term memory1. Symposium contribution. Canadian Journal of Plant Pathology, Otawa, v. 28, p. S280-S287, 2006.

SILVA, A. N.; AZEVEDO, G. B.; ROCHA-SOBRINHO, G. G.; NOVAES, Q. S.; Efeito de produtos químicos e de Trichoderma spp. no controle de Fusarium solani do maracujazeiro. Interciencia, v. 6, p. 398-403, 2014.

SILVA, C. A. D., DE MEDEIROS, E. V., BEZERRA, C. B., DE MORAIS; SILVA, W., DE BARROS, J. A., \& DOS SANTOS, U. J. Interferência da incorporação de matéria orgânica no solo no controle da podridão negra da mandioca, causada por Scytalidium lignicola. Biosci. J., Uberlândia, v. 29, n. 6 , p. 1823-1831, Nov./Dec. 2013.

SILVA, C. A. D., Prospecção em fitopatógenicos e avaliação de fontes de matéria orgânica sobre a supressividade da podridão radicular da mandioca. GaranhunsPE, 2013. 77 f. Dissertação (Mestrado em Produção Agrícola). Universidade Federal Rural de Pernambuco - Unidade Acadêmica de Garanhuns, 2013.

SILVA, H. S. A.; ANDRADE, E. C. Impacto potencial das mudanças climáticas sobre as doenças da mandioca no Brasil. In: Impactos das mudanças climáticas sobre doenças de importantes culturas no Brasil. Jaguariúna: Embrapa Meio Ambiente, p. 263-272, 2011.

SILVA, J. L.; TEIXEIRA, R. N. V. Esporulação e crescimento micelial de Fusarium solani em diferentes meios de cultura e regimes de luminosidade. Revista Agrombiente On-line,v.6,n.1,p.47-52, 2012. Disponível em: <http://revista.ufrr.br/index.php/agroambiente/article/view/604> 
SILVA, K. S.; REBOUÇAS, T. N. H.; BOMFIM, M. P.; SILVA, D. S.; SÃO JOSÉ, A. R.; BENETT, C. G. S. Atividade antagônica in vitro de isolados de Trichoderma spp. ao fungo Phytophthora citrophthora. Londrina. Semina: Ciências Agrárias, v. 29, n. 4, p. 749-754, out./dez. 2008.

SILVA, M.B.; NICOLI, A. COSTA, A.S.V.; BRASILEIRO, B.G.; JAMAL, C.M., SILVA, C. A.; PAULA JÚNIOR, T. J.; TEIXEIRA, H. Ação antimicrobiana de extratos de plantas medicinais sobre espécies fitopatogênicas de fungos do gênero Colletotrichum. Revista Brasileira de Plantas Medicinais , Botucatu, v.10, n.3, p.5760, 2008.

SOUSA, R.M.S.; SERRA, I.M.R.S.; MELO, T.A. Effect of essential oils as an alternative in the control of Colletotrichum gloesporioides in pepper.Summa Phytopathologica, v.38, n.1, p.42-47, 2012.

SOUZA, J. R., Potencialidade de fungicida e agente biológico no controle de requeima do tomateiro. 2013. 63f. Dissertação. Universidade Estadual do Sudoeste da Bahia, Vitória da Conquista. Bahia - BR. 2013.

SOUZA, K. de A.;VAZ, M. C. A.; ALVES, G. C. S.; PAZ -LIMA, M. L.. Confronto in vitro de isolados de Trichoderma spp. com fungos filamentosos. 2p. IV Congresso Estadual de Iniciação Científica do IF Goiano 21 a 24 de setembro de 2015.

SPIEGEL, Y.; CHET, I. Evolution of Trichoderma spp. as a biocontrol agent against soilborne fungi and plant parasitic nematodes in Israel. Integrated Pest Management Review, v. 03, p. 167-175, 1998.

STANGARLIN, J.R. et al. Controle de doenças de plantas por extratos de origem vegetal. Revisão Anual de Patologia de Plantas, v.16, p.265-304, 2008.

URBEN, A.F., et al., Curso taxonomia de Fusarium. Embrapa recursos genéticos e biotecnologia. Brasilia-DF: Embrapa informação tecnólogica, 2009. 
VENTURA, J. A. Taxonomia de Fusarium e seus segregados: I- história, meios e procedimentos de cultivo. Revisão Anual de Patologia de Plantas, Passo Fundo, v. 7, p. 271-298, 1999.

VINALE F, SIVASITHAMPARAM, K., GHISALBERTI, E. L., MARRA, R., WOO, S. L., \& LORITO, M.. Trichoderma-plant-pathogen interactions. Soil Biology and Biochemistry, v. 40, p.1-10.2008.

ZUCCHI, F. O. Trichoderma sp. em áreas agrícolas visando o controle de doenças fúngicas de raízes de plantas cultivadas. Campinas SP. JV Biotecnologia. 15p. 2010.

\section{APÊNDICE - REFERÊNCIA DE NOTA DE RODAPÉ}

1. WOLLENWEBER, H. W.; REINKING, O. A.. Die fusarien: ihre beschreibung, schadwirkung und bekämpfung. Berlin: P. Parey, 1935

Sent: May, 2020.

Approved: June, 2020. 